\title{
Myotubular Myopathy: Arrest of Morphogenesis of Myofibres Associated with Persistence of Fetal Vimentin and Desmin Four cases compared with fetal and neonatal muscle
}

\author{
Harvey B. Sarnat
}

\begin{abstract}
Vastus lateralis muscle biopsies of four unrelated male neonates showing myotubular (i.e. centronuclear) myopathy (MM) were compared with muscle from four human fetuses in the myotubular stage of development, a 31 week preterm infant and four term neonates. The perimysium, blood vessels, spindles, myelinated intramuscular nerves, and motor end-plates in $\mathrm{MM}$ are as well developed as in term neonatal muscle. The cytoarchitecture of myofibres in $\mathrm{MM}$ is more mature than that of fetal myotubes in the spacing of central nuclei, Z-band registry, development of the sarcotubular system, and in the condensation of nuclear chromatin and nucleoli. Triads in MM may retain an immature oblique or longitudinal orientation. Myofibrillar ATPase shows normal differentiation of fibre types, consistent with normal innervation. Spinal motor neurons are normal in number and in RNA fluorescence. Immunoreactivity for vimentin and desmin in myofibres of $\mathrm{MM}$ is uniformly strong, as in fetal myotubes and unlike mature neonatal muscle. Maternal muscle biopsies of two cases also showed scattered small centronuclear myofibres reactive for vimentin and desmin. The arrest in morphogenesis of fibre architecture in $\mathrm{MM}$ is not a general arrest in muscle development. Persistence of fetal cytoskeletal proteins that preserve the immature central positions of nuclei and mitochondria may be important in pathogenesis. Vimentin/desmin studies of the infant and maternal muscle biopsies are useful in establishing the diagnosis.
\end{abstract}

RÉSUMÉ: Myopathie myotubulaire: Arrêt de la morphogenèse des myofibres associé à une persìstance de la vimentine et de la desmine fétales On a comparé des biopsies musculaires du vaste externe prélevées chez quatre nouveau-nés mâles sans lien de parenté, montrant une myopathie myotubulaire (centro-nucléaire MM), à des muscles provenant de quatre foetus humains durant l'étape myotubulaire de développement, d'un enfant prématuré âgé de 31 semaines, et de quatre nouveau-nés à terme. Le périmysium, les vaisseaux sanguins, les fuseaux musculaires, les nerfs myélinisés intramusculaires, et les jonctions neuro-musculaires sont aussi bien développés dans la MM que dans le muscle néo-natal à terme. La cyto-architecture des myofibres dans la MM a un niveau de maturité supérieur à celui des myotubes foetaux en ce qui a trait aux intervalles entre les noyaux centraux, à l'alignement des striations transversales, au développement du système sarcotubulaire, et à la condensation de la chromatine nucléaire et du nucléole. Les triades dans la MM conservent souvent l'orientation oblique ou longitudinale de l'état immature. La différenciation histochimique des myofibres selon l'ATPase myofibrillaire reste mature dans la MM, suggèrant une innervation normale. Les neurones moteurs spinaux sont normaux en nombre et à l'égard de la fluorescence pour l'ARN. L'immunoréactivité pour la vimentine et pour la desmine dans les myofibres de MM est uniformément forte, semblable aux myotubes foetaux et dissemblable au muscle mature néo-natal. Les biopsies musculaires des mères de deux cas montrèrent également des petites myofibres éparses à noyaux centraux, réactives pour la vimentine et pour la desmine. La MM représente un arrêt de la morphogenèse de l'architecture de la myofibre mais non arrêt général du développement musculaire. La pathogenèse est vraisemblablement une presévérance des protéines cytosquelettiques du foetus qui maintiennent la localisation centrale immature des noyaux et des mitochondries. Les études de la vimentine et de la desmine dans les biopsies musculaires de la mère et de l'enfant sont utiles pour établir le diagnostic.

Can. J. Neurol. Sci. 1990; 17: 109-123

From the Departments of Pathology, Paediatrics, and Clinical Neurosciences, University of Calgary Faculty of Medicine, Calgary Presented at the Canadian Congress of Neurological Sciences, Ottawa, Canada, June 13-17, 1989

Received July 18, 1989. Accepted in final form December 4, 1989

Reprint requests to: Dr. H.B. Sarnat, Alberta Children's Hospital, 1820 Richmond Road S.W., Calgary, Alberta, Canada T2T 5C7 

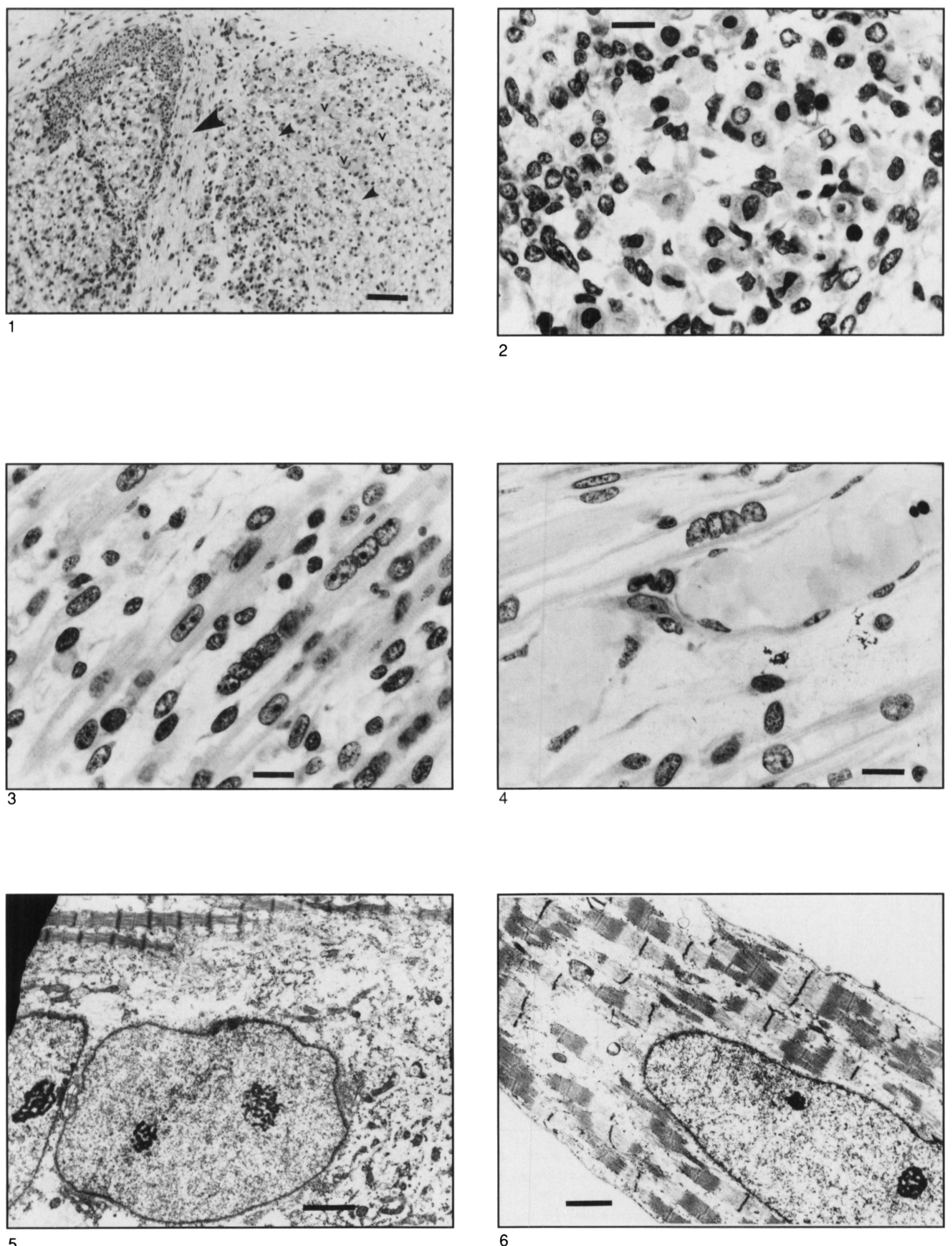
The term "myotubular myopathy" implies a disorder resulting from maturational arrest of embryonic muscle, the expressed intent of Spiro et al. in describing an adolescent boy with mild weakness whose muscle biopsy showed centronuclear myofibres.' Subsequent authors often have made the same assumption or assertion about persistent fetal myotubes. ${ }^{2-5}$ The concept was reinforced by the lack of change in the myotubular appearance of muscle fibres in the same patient from the neonatal period to later infancy. ${ }^{5}$ The conclusion that the disease was due to persistent fetal muscle was soon questioned by Sher et al., ${ }^{6}$ and by Munsat et al. who found mature rather than fetal myoglobin in the muscles of affected infants, as in the normal term neonate. ${ }^{7}$ A few authors compared muscle from myotubular myopathy with true fetal muscle, but the results were inconclusive. 3,8

The more neutral and descriptive term "centronuclear myopathy" is preferred by many authors because it avoids pathogenetic inferences, but this terminology is also less than satisfactory because of its lack of specificity; internal nuclei occur as a secondary phenomenon in many myopathies and in chronic states of denervation.

The recognition of three modes of genetic transmission identifies myotubular myopathy as more than a single disease. The best documented form is $\mathrm{X}$-linked recessive, $8-16$ and it is this form that is most common, particularly in infantile cases. ${ }^{16}$ Autosomal dominant inheritance is demonstrated in some families,4,17-19 Most are older children or adults, but some are already symptomatic at birth. ${ }^{19}$ An autosomal recessive form also is proposed.6,20.21 Clinical expression varies greatly regardless of genetic transmission trait. Some cases are severe in the neonatal period, with respiratory insufficiency often leading to early death. $5,11,13,22-27$

The controversy whether myotubular myopathy is a true maturational arrest of fetal muscle remains unresolved and the pathogenesis is still highly speculative. Congenital anomalies of other systems that may be dated from the myotubular stage of development are not associated. The appearance of a craniopharyngioma in one boy with a centronuclear myopathy is probably fortuitous. ${ }^{28}$ Similarly, a single case report of multiple congenital anomalies and myotubular myopathy, ${ }^{29}$ and this myopathy in a patient with Marfan syndrome ${ }^{30}$ do not suggest a common etiology. The ontogenesis of striated muscle in humans is well characterized in terms of morphological, ultrastructural, and histochemical maturation and is as precisely time-linked as is the development of the nervous system. ${ }^{31-34}$ The purpose of the present study was to compare muscle from four unrelated infantile cases of myotubular myopathy with muscle morphology and ultrastructure from normal human fetuses in the myotubular stage of development at 8-15 weeks gestation and from normal premature and term neonates. Immunoreactivity for the fetal intermediate filament proteins vimentin and desmin, an aspect not previously studied, also were examined. Maternal muscle biopsies were studied in three of the four cases.

\section{MATerials AND Methods}

Four well-formed human fetuses ranging in postconceptional age from 8-15 weeks were available from therapeutic abortions. None had gross congenital malformations or stigmata of genetic disease. There was no family history of neuromuscular or genetic disease in any case.

A surgical muscle biopsy was performed in a 12-day-old preterm infant born at 29 weeks gestation to rule out myopathy as a cause of lack of respiratory drive. Four full-term neonates underwent surgical muscle biopsies because of hypotonia and suspected congenital myopathies. These biopsies, all interpreted as normal, served as additional controls.

Four unrelated male neonates with clinical signs of severe myopathy had muscle biopsies fulfilling the criteria of myotubular myopathy. Patient I was born at term weighing $3300 \mathrm{~g}$ and survived 9 months, when he died of an unsuspected haemangioma of the liver that ruptured spontaneously. A complete autopsy was performed and the clinical and pathological details of this case were reported previously. ${ }^{5}$ Muscle tissue was still available for further study at this time.

Patient 2 was born by emergency caesarian section at 38 weeks gestation after spontaneous rupture of the membranes and the onset of fetal distress. The pregnancy had been complicated by polyhydramnios and pre-ecclampsia. Birth weight was 2840 $\mathrm{g}$. The infant required incubation at birth, and died at 9 days of age while still dependent upon the respirator. Permission was given for only a limited autopsy that included several muscles, diaphragm, spinal cord and nerve roots.

Patient 3 was delivered at 32 weeks gestation by emergency caesarean section for fetal distress and polyhydramnios. Birth weight was $1855 \mathrm{~g}$. The infant was intubated at birth and remained dependent upon the ventilator until his death at 7 weeks. Muscle biopsy was performed at 34 days of age, at a conceptional age of 36 weeks.

Figure I - Cross-section through thigh of 12 week human fetus. The fascicular organization of the muscle is rudimentary, with only a few connective tissue septae beginning to divide the muscle (small arrowheads). The large connective tissue septum in the centre (large arrowhead) is the developing capsule that will separate the vastus lateralis (left) from the rectus femoris (right) portions of the quadriceps femoris. Early myotubes tend to aggregate in the periphery of the developing muscle, and more mature myonubes in the centre. No muscle spindles are formed. A few' blood vessels (v) penetrate the muscle as thin-walled channels. Haematoxylin-eosin. Bar $=100 \mu \mathrm{m}$.

Figure 2 - Cross-section of myotubes in 14 week fetus. Early myotubes have only a thin rim of cytoplasm around the nucleus. and late myotubes are much thicker with more myofibrils. Haematoxylin-eosin. Bar $=15 \mu \mathrm{m}$.

Figure 3 - Longitudinal section of 14 week fetus. Nuclei are large and vesicular and have prominent mucleoli. Some are spaced apart from one another with a central core of intervening sarcoplasm, and others are tiqhtly apposed as a packed column with no intervening sarcoplasm. Haematoxylin-eosin. Bar $=12 \mu \mathrm{m}$.

Figure 4 - Intramuscular vascular channel in a 12 week human fetus. Endothelial cells have sparse cytoplasm and small nuclei, and no smooth muscular walls are formed around even the channels with the largest lumens. Semithin plastic section. Haematoxylin-eosin. Bar $=10 \mu m$

Figures 5, 6-Central nuclei of myotubes of (Figure 5) 12 week and (Figure 6) 14 week fetuses. The large muclei have finely dispersed chromatin. Nucleoli consist of reticular nucleolonemi. Z-bands of adjacent myofibrils are not in register. EM. Bar $=($ Figure 5$) 2 \mu m ;($ Figure 6$) 2 \mu m$. 

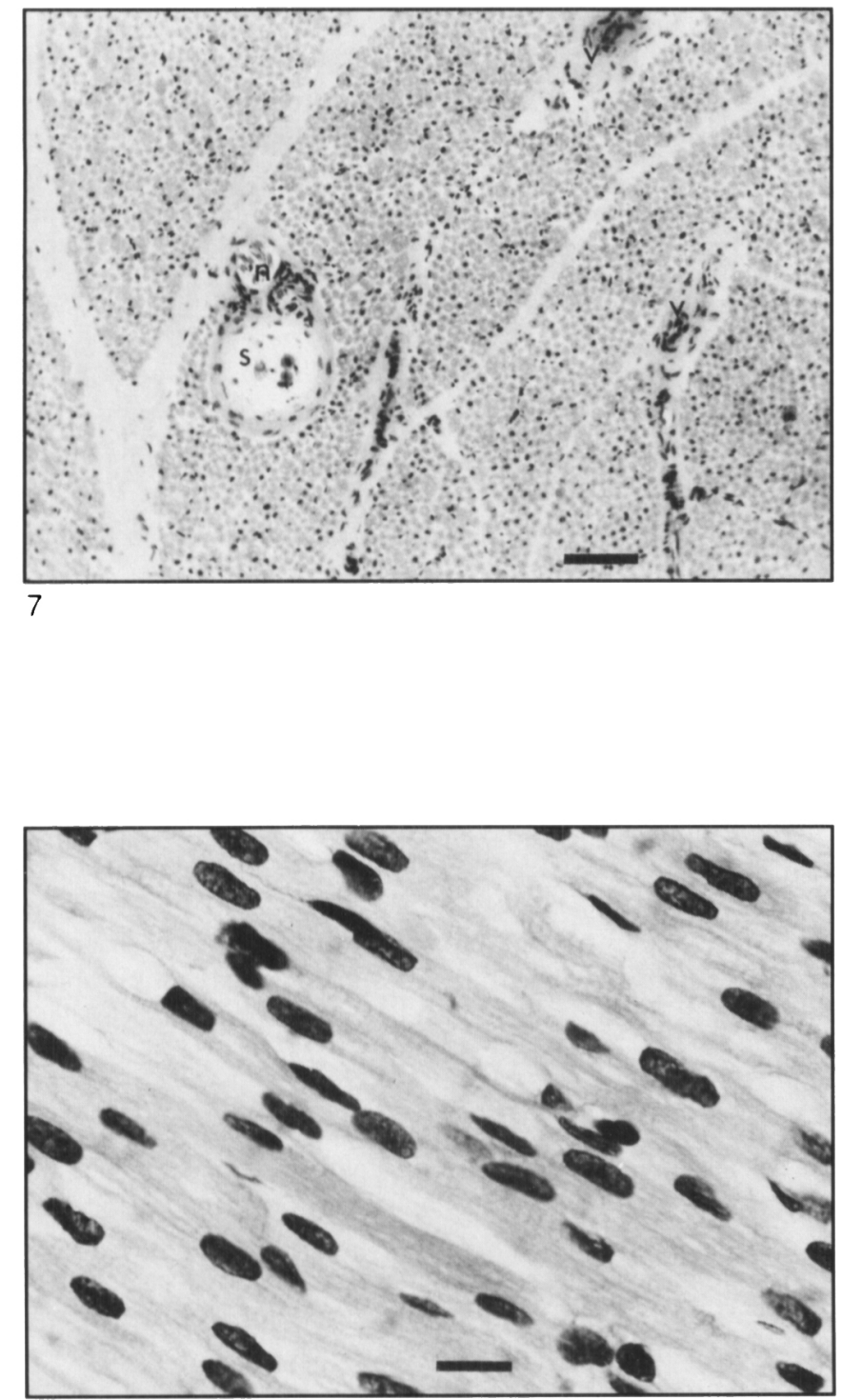

9
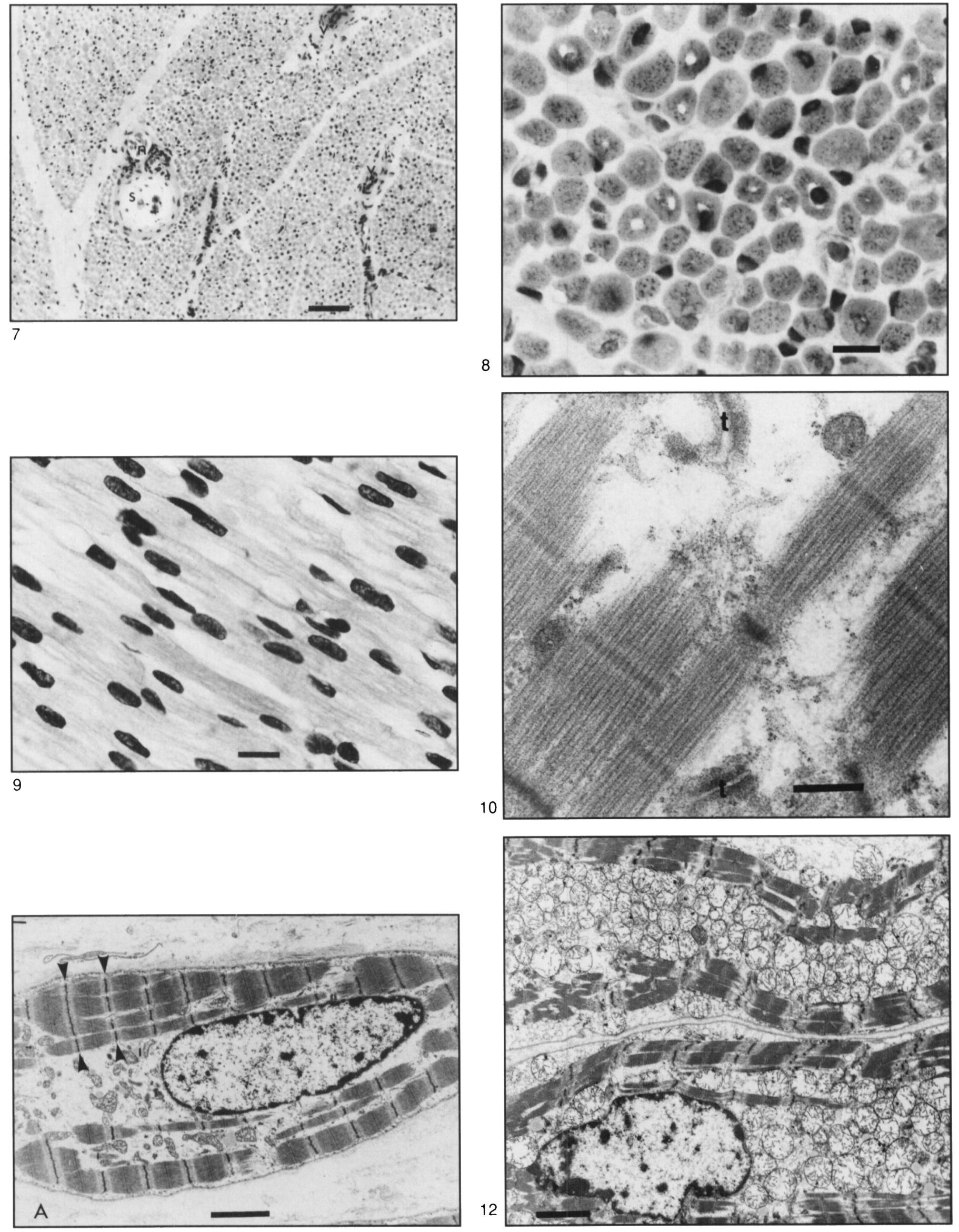
Patient 4 was a $3145 \mathrm{~g}$ full-term infant who had respiratory insufficiency at birth and required incubation. Macrognathia and multiple joint contractures were present. He died at three days of age with bilateral pneumothoraces and increasing difficulty with mechanical ventilation.

Though Patient 1 was less severe than the others and did not require mechanical ventilation, all four infants showed generalized muscular hypotonia, diffuse weakness, minimal spontaneous motor activity, areflexia, and a thin muscle mass in the extremities. Gavage feeding or parental nutrition was required in all. Except for facial weakness and high palates in all cases and contractures in one infant, no congenital anomalies were detected. The hepatic haemangioma was not detected in Patient 1 until after death. Chromosomes showed a normal $46 \mathrm{XY}$ karotype in all cases.

Family histories in all three cases were negative for documented neuromuscular disease. Patients 1 and 3 were born to primigravida mothers. Patient 2 was born to a gravida 4 mother who had 3 previous normal children, two girls and a boy. Patient 4 was also born to a gravida 4 mother, but her previous pregnancies had terminated in two spontaneous abortions and one liveborn male infant who died in the neonatal period of "congenital heart disease". Autopsy was not performed.

The vastus lateralis (quadriceps femoris) muscle was studied in all fetuses and infants including the neonatal controls. Muscle tissue was rapidly frozen in isopentane cooled to $-160^{\circ} \mathrm{C}$ in liquid nitrogen and transverse sections of $6 \mu \mathrm{m}$ were cut in a cryostat. Standard techniques were applied for the following histological and histochemical stains: haematoxylin-eosin; modified Gomori trichrome; periodic acid-Schiff reaction; oil red 0 ; total myophosphorylase; nicotinamide adenine dinucleotide-tetrazolium reductase (NADH-TR); acid phosphatase; calcium-mediated myofibrillar adenosine triphosphatase (ATPase) preincubated at

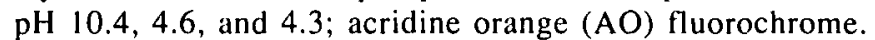
Unstained sections also were examined in the fluorescence miscroscope for autofluorescent lipochrome pigment. An additional portion of the muscle biopsy was fixed in $10 \%$ buffered formalin and embedded in paraffin for longitudinal and transverse histological sections. A portion of each muscle was fixed in $2 \%$ glutaraldehyde and processed for transmission electron microscopy (EM) by embedding in epoxy resin and staining thin longitudinal and transverse sections with osmium tetroxide and lead citrate.

Additional unfixed frozen and formalin-fixed paraffin sections were stained for peroxidase-antiperoxidase immunoreactivity for vimentin and for desmin, using mouse monoclonal antibodies (Biogenex ${ }^{R}$ MA-074-5C and MA-072-5C). Dilutions of 1:50 were used. Sections of fetal and neonatal muscle were incubated simultaneously.

The mothers of three infants with myotubular myopathy consented to muscle biopsy of themselves. The tissue from the mother of Patient 1 was no longer available for vimentin and desmin studies, but other features were studied. ${ }^{5}$ The mothers of Patients 3 and 4 are here reported.

At autopsy, the brains of Patients 1, 3, and 4, and the spinal cords of all four patients with myotubular myopathy were removed and prepared for neuropathological examination according to standard methods. Paraffin-embedded sections of lumbar spinal cord were compared with age-matched controls, but serial sections for quantitative counts of motor neurons were not performed.

Some spinal cord sections were stained with $A O$ and examined in the fluorescence microscope. Vimentin immunoreactivity was examined in fetal, neonatal, and myotubular myopathy spinal motor neurons. Segments of ventral nerve roots were fixed in $2 \%$ glutaraldehyde and prepared for electron microscopic examination; other segments were fixed in formalin, paraffin-embedded, and stained with haematoxylin-eosin and luxol fast blue. Multiple muscle samples were taken from the diaphragm, intercostal muscles, and upper and lower extremities. Some portions of muscle were frozen in a cryostat for histochemistry and studied as with the surgical muscle biopsies; others were fixed in formalin or in glutaraldehyde for histological and EM examination.

\section{RESULTS}

The comparison of striated muscle from the vastus lateralis and other muscles from the early fetuses, the 31 week premature infant, and from the term neonates is summarized in Table 1.

Figure 7 - Cross-section of vastus lateralis muscle of term neonate with myoubular myopathy. The fascicular organization of the muscle is as well developed as in the normal term neonate with well formed connective tissue septae. A muscle spindle ( $s$ ) is seen. intramuscular nerves (n) are well formed, and mature blood vessels with muscular walls (v) as well as capillaries are developed. Haematoxylin-eosin. Bar $=75 \mu m$.

Figure 8-Cross-section of myofibres in myotubular myopathy. Centronuclear fibres resemble late myoubes in being a thick cylinder of contractile proteins surrounding a central row of nuclei with intervening sarcoplasm in the core. Scattered myofibres appear more mature with peripheral sarcolemmal nuclei and uniformly distributed sarcoplasmic membranous structures between myofibrils. Modified Gomori richrome. Bar $=15 \mu m$.

Figure 9-Longitudinal section of muscle in myotubular myopathy. The central nuclei are elongated and are spaced several nuclear diameters apart from one another, rather than as a tightly packed column. Haematoxylin-eosin. Bar $=30 \mu \mathrm{m}$.

Figure 10 - In neonatal myotubular myopathy, triads $(t)$ have a random orientation, longitudinal, oblique, or perpendicular to the long axis of the myofibre. This is an immature feature resembling the 20-32 week fetus, but unlike the 8-15 week fetus, triads are well formed. Bar $=1.5 \mu m$.

Figure 11 - Central myofibre nuclei in myotubular myopathy show variable condensation of nuclear chromatin, often less than in the 31 week or term neonate hut more than in the 14 week fetus. Nucleoli are much more compact than in the fetus and have a density similar to the normal term neonate. Mitochondria are mainly central and centripetal in distribution. Z-bands are in register (arrowheads). Reproduced from Can J Neurol Sci 1981:8:313-320.EM. Bar $=4 \mu \mathrm{m}$.

Figure 12 - Longitudinal section of two myofibres of diaphragm of term neonate with myoubular myopathy show's large mumbers of tightly packed mitochondria in the central core between central nuclei. In addition to the abnormal distribution, the number of mitochondria greatly exceeds that seen in the normal term neonate, even though myofibres in the diaphragm normally have more numerous mitochondria than those from muscles of the extremities, $E M$. Bar $=5 \mu \mathrm{m}$. 
Table 1: Comparison of Striated Muscle from Human Fetuses, Neonates and Patients with Neonatal Myotubular Myopathy

\begin{tabular}{|c|c|c|c|c|}
\hline & 8-15 week fetus & 31 week fetus & 40 week infant & $\begin{array}{l}\text { myotubular } \\
\text { myopathy }\end{array}$ \\
\hline \multicolumn{5}{|l|}{ ORGANIZATION OF MUSCLE } \\
\hline Perimysium & unformed & well formed & well formed & well formed \\
\hline Blood Vessels & thin-walled channels & $\begin{array}{l}\text { arterioles, venules } \\
\text { and capillaries }\end{array}$ & $\begin{array}{l}\text { arterioles, venules } \\
\text { and capillaries }\end{array}$ & $\begin{array}{l}\text { arterioles, venules } \\
\text { and capillaries }\end{array}$ \\
\hline Spindles & unformed & well formed & well formed & well formed \\
\hline Nerves & unmyelinated & myelinated & myelinated & myelinated \\
\hline Neuromuscular Junctions & few; simple & many; mature & many; mature & many; mature \\
\hline \multicolumn{5}{|l|}{ MYOFIBRE MORPHOLOGY } \\
\hline Nuclear Position & $\begin{array}{l}\text { central row; closely and } \\
\text { widely spaced in fibre }\end{array}$ & $\begin{array}{l}\text { peripheral; widely } \\
\text { spaced }\end{array}$ & $\begin{array}{l}\text { peripheral; widely } \\
\text { spaced }\end{array}$ & $\begin{array}{l}\text { central row; widely } \\
\text { spaced }\end{array}$ \\
\hline Nuclear Chromatin & fine & coarse & coarse & coarse or fine \\
\hline Z-band register & absent & present & present & present \\
\hline Mitochondria & central & intermyofibrillar & intermyofibrillar & central \\
\hline Triads & unformed & $\begin{array}{l}\text { oblique or perpendicular } \\
\text { to long axis }\end{array}$ & $\begin{array}{l}\text { perpendicular to long } \\
\text { axis }\end{array}$ & $\begin{array}{l}\text { oblique or perpendicular } \\
\text { to long axis }\end{array}$ \\
\hline Glycogen & central and myofibrillar & intermyofibrillar & intermyofibrillar & central \\
\hline Ribosomes & $\begin{array}{l}\text { many; associated with } \\
\text { myosin synthesis }\end{array}$ & few & few & $\begin{array}{l}\text { fewer than } 15 \text { week } \\
\text { fetus }\end{array}$ \\
\hline Basal Lamina & encloses $1-3$ myotubes & encloses 1 myofibre & encloses 1 myofibre & encloses 1 myofibre \\
\hline Presumptive Myoblasts or & many; frequent mitoses & fewer than 15 week & few; rare mitoses & few; rare mitoses \\
\hline Satellite Cells & & fetus; few mitoses & & \\
\hline Myoblast Fusion & present & absent & absent & absent \\
\hline \multicolumn{5}{|c|}{ HISTOCHEMISTRY OF MYOFIBRES } \\
\hline Oxidative Enzymes & $\begin{array}{l}\text { central and } \\
\text { subsarcolemmal; no } \\
\text { type differentiation }\end{array}$ & $\begin{array}{l}\text { intermyofibrillar; type } \\
\text { differentiation }\end{array}$ & $\begin{array}{l}\text { intermyofibrillar; type } \\
\text { differentiation }\end{array}$ & $\begin{array}{l}\text { central and } \\
\text { subsarcolemmal; no } \\
\text { type differentiation }\end{array}$ \\
\hline Periodic Acid-Schiff reaction & $\begin{array}{l}\text { central; no type } \\
\text { differentiation }\end{array}$ & $\begin{array}{l}\text { intermyofibrillar; type } \\
\text { differentiation }\end{array}$ & $\begin{array}{l}\text { intermyofibrillar; type } \\
\text { differentiation }\end{array}$ & $\begin{array}{l}\text { central; no type } \\
\text { differentiation }\end{array}$ \\
\hline Myofibrillar ATPases & no type differentiation & $\begin{array}{l}\text { type differentiation; } \\
\text { subtypes of II }\end{array}$ & $\begin{array}{l}\text { type differentiation; } \\
\text { subtypes of II }\end{array}$ & $\begin{array}{l}\text { type differentiation; } \\
\text { subtypes of II }\end{array}$ \\
\hline Acid Phosphatase & $\begin{array}{l}\text { present in scattered } \\
\text { myotubes }\end{array}$ & absent from myofibres & absent from myofibres & absent from myofibres \\
\hline Acridine Orange-RNA Fluorescence & strong & absent & absent & $\begin{array}{l}\text { weak or moderate in } \\
\text { some myofibres; absent } \\
\text { in most }\end{array}$ \\
\hline MYOGLOBIN ${ }^{7}$ & fetal type & $\begin{array}{l}\text { mixed fetal and mature } \\
\text { types }\end{array}$ & mature type & mature type \\
\hline \multicolumn{5}{|c|}{ IMMUNOREACTIVITY OF MYOFIBRES } \\
\hline Vimentin & strong & weak & nil & moderate or strong \\
\hline Desmin & strong & weak & nil & strong \\
\hline CELL DEATH & $\begin{array}{l}\text { scattered degenerating } \\
\text { myotubes }\end{array}$ & no degeneration & no degeneration & no degeneration \\
\hline
\end{tabular}

Unlike the absent or rudimentary perimysial connective tissue septae of fetal muscle in the myotubular stage (Figure 1), the fascicular organization of muscle in myotubular myopathy (Figure 7) is as mature as in the term neonate and is already well formed by 31 weeks. Blood vessels are not the thin-walled vascular channels lined by endothelial cells with sparse cytoplasm found in the fetus (Figure 4), but rather mature capillaries as well as arterioles and venules with muscular walls.

Muscle spindles are unformed in fetal muscle before 15 weeks, but fully developed spindles are seen in myotubular myopathy, as at 31 weeks and at term (Figure 13). Intrafusal muscle fibres of both the nuclear bag and nuclear chain varieties are found, the spindle capsule is well formed, and intracapusular nerve fibres are seen in some.

Intramuscular nerves in myotubular myopathy are well formed and have myelin sheaths of normal thickness (Figure 14), indistinguishable from those in the term infant. No degenerative changes are seen in the axoplasm. Schwann cells enclose single myelinated axons or several small unmyelinated nerve fibres. Motor end-plates have normal morphology. In the 
fetus, nerves are sparse and unmyelinated, and neuromuscular junctions are rudimentary with simple folds of the postsynaptic membrane.

Both fetal myotubes and the myofibres of myotubular myopathy show a single row of nuclei within a central core of cytoplasm surrounded by a rim of myofibrils. Sarcolemmal nuclei are peripheral in term neonatal muscle. However, there are differences in both arrangement and morphological details of the central nuclei between fetal myotubes and myotubular myopathy fibres. In myotubular myopathy, the nuclei are nearly always spaced several nuclear diameters apart, with intervening sarcoplasm (Figure 9); the spacing of central nuceli in fetal myotubes is much more variable. Some fibres show a line of closely spaced nuclei with no intervening cytoplasm and others have irregularly and widely spaced nuclei (Figure 3). Closely and widely spaced nuclei occur along different segments of the same myotube. The spacing of the peripheral subsarcolemmal nuclei at 31 weeks and at term is similar to the spacing in myotubular myopathy.

In the fetus, the nuclei are large, vesicular, and ovoid. Mature subsarcolemmal nuclei at term are more elongated, more narrow, and denser. Electron microscopy reveals finely dispersed chromatin and one or two nucleoli composed of open reticular nucleolonemi (Figures 5,6). In the term neonate and the 31 week infant, nuclei consist of heterochromatin aggregates and additional condensations along the inner nuclear membrane; the nucleoli are also denser and more compacted (Figures 15, 16). In myotubular myopathy, the density of chromatin is variable. Some nuclei show fine particulate chromatin and in others it is as condensed as in the term neonate (Figure 11); most nuclei have coarser chromatin and nucleoli than in fetal myotubes, but not quite as coarse as at term.

Fetal myotubes vary greatly in the thickness of the tube of myofibrils and consequently the diameter of the myofibre. Early and late myotubes are found together, with sparse or abundant contractile filaments, respectively (Figure 2). In myotubular myopathy, fibres resembling early myotubes are not found and all of the centronuclear fibres are thick, though smaller than the

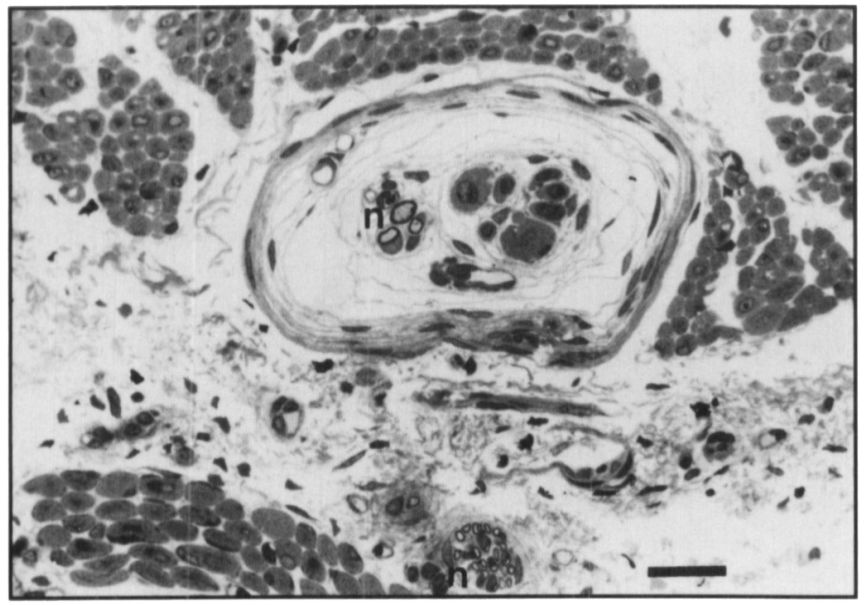

Figure $13-$ Muscle spindle in infant with myotubular myopathy. Intrafusal muscle fibres are well developed and larger than the small centronuclear extrafusal fibres. Myelinated nerves $(n)$ are included within the spindle capsule. An intramuscular nerve $(n)$ not associated with the spindle is seen at the bottom of the figure. Semithin plastic section. Toluidine blue. Bar $=50 \mu \mathrm{m}$.

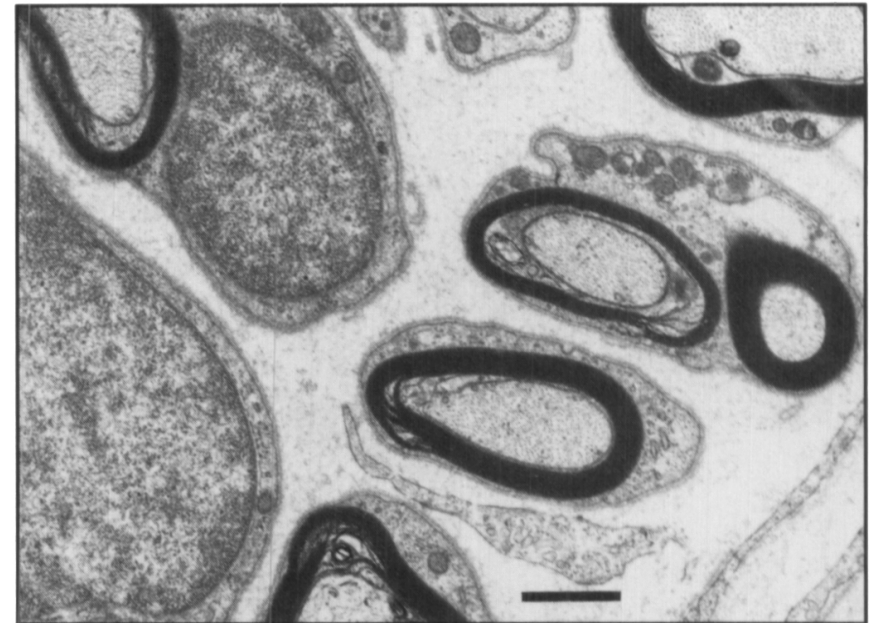

Figure 14 - Intramuscular nerve in term infant with myotubular myopathy shows normal Schwann cells and myelinated axons, indistinguishable from those seen in the normal term neonate. EM. Bar = $I \mu m$.

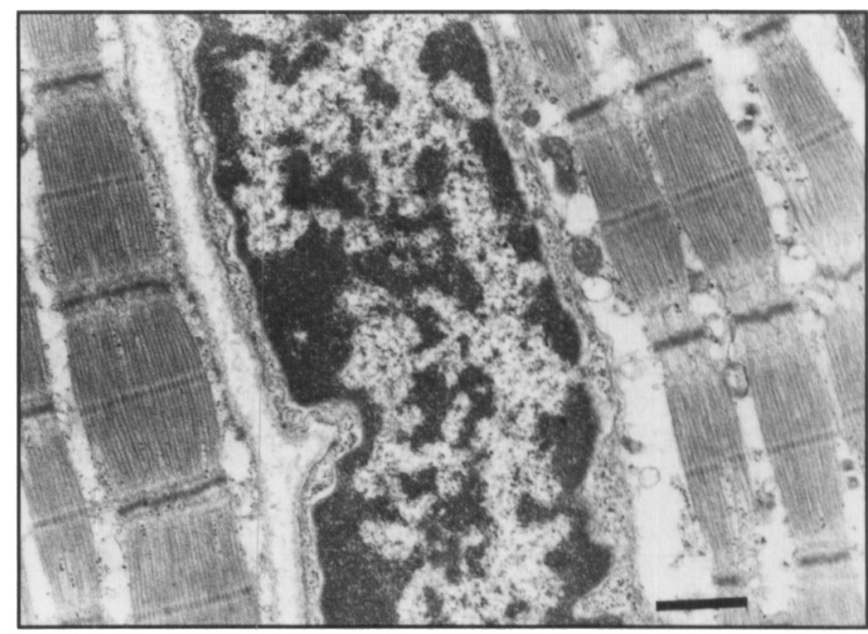

Figure 15 - Peripheral sarcolemmal nucleus of preterm infant of 31 weeks conceptional age shows dense clumping of nuclear chromatin, especially along the inner nuclear membrane. This condensation is similar to that seen in the term neonate. Some but not all Zbands are in register. EM. Bar $=1.5 \mu \mathrm{m}$.

$15 \mu \mathrm{m}$ mean diameter of mature fibres in the term neonate (Figure 8). Scattered amongst the centronuclear fibres in myotubular myopathy are a few large, mature-appearing myofibres with peripheral nuclei and mitochondria distributed throughout the intermyofibrillar spaces. These large (i.e. normal size) "mature" myofibres constitute about ten percent of total myofibres and are never grouped.

Z-band register, the alignment of Z-bands of adjacent myofibrils within a myofibre, is lacking in fetal myotubes (Figure 6), but is well developed in both myotubular myopathy (Figure 11) and in the term neonate (Figure 16) and the 31 week preterm infant (Figure 15).

Mitochondria are well formed with cristae in the fetus, in the term neonate, and in myotubular myopathy. The mitochondria are concentrated in the central core of sarcoplasm and around the nuclei, in a centripetal distribution in myotubular myopathy (Figures 11,12 ) as in the fetal myotube, but are redistributed in 


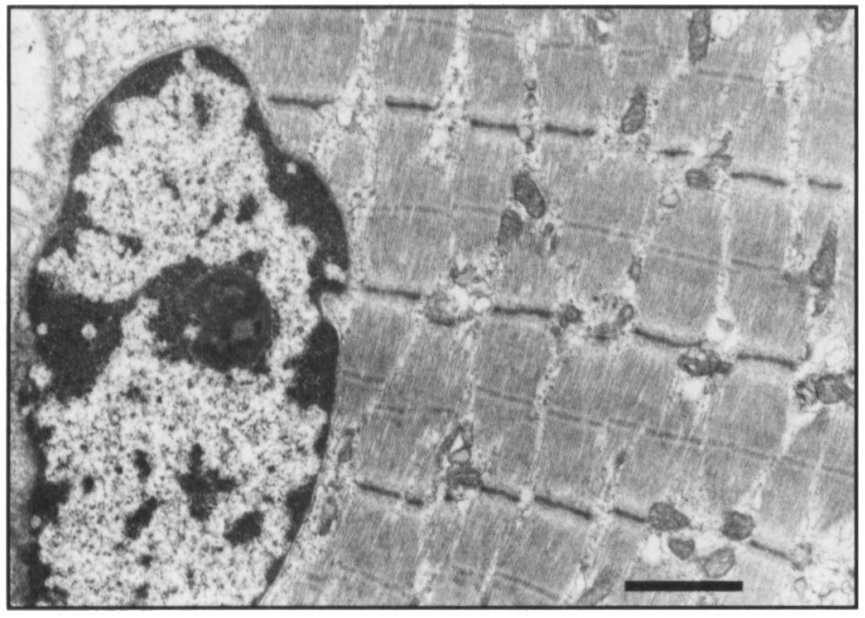

Figure 16 - Peripheral sarcolemmal nucleus of full-term normal neonates shows condensation of chromatin along inner membrane and within nucleoplasm. Nucleolus is a condensed sphere. The Zbands are well aligned in register and mitochondria are distributed between myofibrils. EM. Bar $=1.5 \mu \mathrm{m}$.

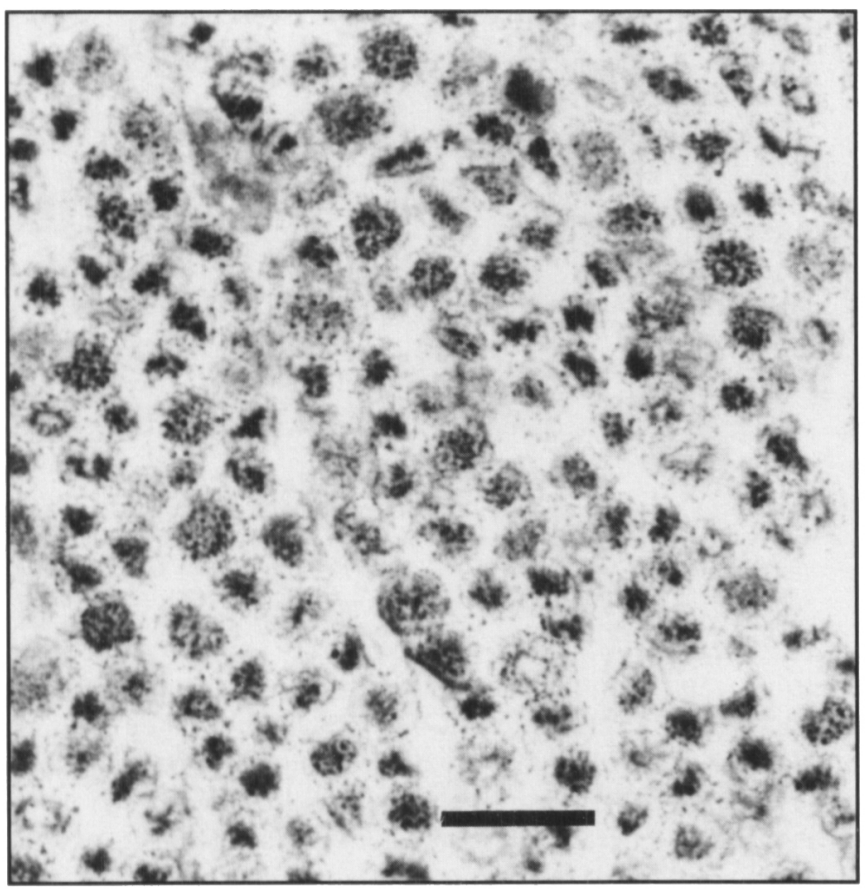

Figure 17 - Frozen cross-section of muscle from infant with myotubular myopathy, stained with NADH-TR. Oxidative enzymatic activity is highly concentrated in the centres of myofibres at levels between nuclei and in the subsarcolemmal region, with an intervening rim of unstained myofibrils. This is the characteristic appearance of fetal myotubes with this histochemical stain. The enzymatic activity is mostly mitochondrial (see Figure 14). A few larger myofibres have more uniformly distributed points of mitochondrial oxidative enzymatic activity as is characteristic of the mature myofibre. Bar $=30$ $\mu m$. the intermyofibrillar sarcoplasm in the preterm and term neonates. Large aggregates of mitochondria in the central core between nuclei were especially prominent in muscle fibres of the diaphragm in myotubular myopathy (Figure 12). Mitochondria are more numerous in the diaphragm than in muscles of the extremities even in normal term neonates, but not to the extreme degree found in myotubular myopathy.

Glycogen granules had a distribution similar to the mitochondria but were more abundant in fetal myotubes than in myotubular myopathy. In fetal muscle they also were common within myofibrils, between myofilaments.

Triads, composed of a transverse tubule (formed by invagination of the plasma membrane of the myofibre) surrounded by a pair of terminal cisternae of the sarcoplasmic reticulum, are yet unformed in the fetus at the myotubular stage. They are well formed by term. In muscle from the 31 week preterm infant and from all cases of myotubular myopathy examined (Figure 10), triads were well formed, but their orientation was not perpendicular to the long axis of the myofibre as at term; they were oriented longitudinally and obliquely, in immature positions.

Ribosomes are numerous in fetal muscle, particularly at the ends of sarcomeres at sites of myosin filament assembly. They are rare in neonatal muscle. Some myofibres in myotubular myopathy had more free rihosomes than in the term infant, but never as many as in fetal myotubes.

Basal laminae (i.e. basement membranes) enclose 1 to 3 myotubes in the fetus, but enclose only single myofibres in older infants and in myotubular myopathy. Presumptive myoblasts enclosed within the basal lamina are numerous in fetal myotubes and mitotic figures of their nuclei are frequent. Presumptive myoblasts are less common in myotubular myopathy and have a frequency similar to that of neonatal muscle. Mitosis are rare in myotubular myopathy or in normal term neonatal muscle. Myoblast fusion is seen only in fetal muscle.

Histochemical stains for oxidative enzymatic activity (NADH-TR) and for glycogen (PAS) were nearly identical in fetal myotubes and in myotubular myopathy (Figure 17). The activity was localized to the central core of sarcoplasm at levels between nuclei, with an additional thin rim in the subsarcolemmal region. In the 31 week preterm infant and the term neonates, the NADH-TR activity and PAS-positive granules were uniformly distributed in the intermyofibrillar sarcoplasm. The distribution of these products in myotubular myopathy precludes identification of histochemical fibre types with these stains. Acid phosphatase activity is seen in scattered fetal myotubes, but not in mature muscle or in myotubular myopathy.

Myofibrillar ATPase stains show good differentiation of fibre types including subtypes of II by ATPase stains (Figure 18). A mosaic distribution of fibre types is seen, with a slight preponderance of type I fibres, normal for the vastus lateralis muscle in early infancy. In fetal muscle, ATPase does not distinguish fibre types at any preincubation $\mathrm{pH}$, and staining is uniform.

Acridine orange (AO) fluorochrome shows intense orange RNA staining of fetal myotubes (Figure 19). Mature myofibres in neonatal muscle show only a green background fluorescence of proteins without nucleic acids (Figure 20). In muscle from myotubular myopathy, the majority of myofibres also are green with yellow DNA nuclei (Figure 21, 22). Scattered small groups of myofibres have an orange fluorescence, though never as strong as in fetal myotubes. Immunoreactivity for vimentin and 
desmin were strong in fetal myotubes (Figures 23, 28) and also in all cases of myotubular myopathy, uniformly throughout all myofibres (Figures 25-27, 30, 31). Intrafusal spindle fibres reacted for vimentin and desmin as well as extrafusal myofibres (Figure 31). Reactions were weak but still detected in the preterm infant of 31 weeks and completely negative in all of the term infants (Figures 24, 29). In each case, unfixed frozen sections showed stronger activity than did the formalin-fixed, paraffin-embedded tissue, but the latter also was positive in both fetal myotubes and in myotubular myopathy. Unstained frozen and paraffin-embedded sections of muscle showed no autofluorescent lipochrome in any case.

The spinal cords of the infants with myotubular myopathy appeared normal microscopically. No gliosis was seen in the parenchyma of the cord, and the number of motor neurons in the ventral horns was similar to that observed in age-matched controls in lumbar segments. Motor neurons had normal morphology with Nissl granules filling the cytoplasm. AO showed similar intensity and distribution of RNA fluorescence in motor neurons from cases of myotubular myopathy (Figure 32) and normal term neonates. Vimentin immunoreactivity was negative in motor neurons in both myotubular myopathy and in term neonates, and weakly positive in immature motor neurons of the fetal spinal cord. No pathological alterations were detected in ventral or dorsal nerve roots or in dorsal root ganglia. The brain was normal and consistent with the conceptional age in the two cases examined.

The maternal muscle biopsy of Patients 3 and 4 showed only minimal histological alterations. Scattered myofibres comprising about 5 percent of total had central nuclei which were arranged as a central row of evenly spaced nuclei about 1-2 nuclear diameters apart; these fibres were smaller than normal, measuring 28-35 $\mu \mathrm{m}$ (normal mean $60 \mu \mathrm{m}$ ), and ATPase stains revealed them to be type I. Other small polygonal or angular myofibres with peripheral sarcolemmal nuclei also were distributed throughout the biopsy and were nearly all type I fibres by ATPase criteria. No fibres showed orange-red RNA fluorescence with AO. Several of the small centronuclear fibres in both frozen and paraffin sections showed strong immunoreactivity for desmin (Figure 33). These same fibres also were reactive for vimentin, though only weakly. No abnormal muscle fibres were seen in the small sample examined by electron microscopy.

\section{DISCUSSION}

In comparing muscle from neonates with myotubular myopathy with human fetal muscle during the myotubular stage of development, it becomes evident that only certain features of myofibre architecture and a strong immunoreactivity for vimentin and desmin are similar. In other respects, striated muscle in myotubular myopathy is as mature as in the term neonate. In particular, the perimysium that normally forms at 15-20 weeks divides the muscle into fascicles, muscle spindles that normally form at about 20 weeks are well developed, intramuscular nerves are myelinated and motor end-plates are morphologically mature.

Frequent mitotic figures of presumptive myoblasts and fusion of mononucleated myoblasts and myotubes to form multinucleated myofibres are prominent in fetal muscle but not evident in myotubular myopathy. Various stages of myotube forma-

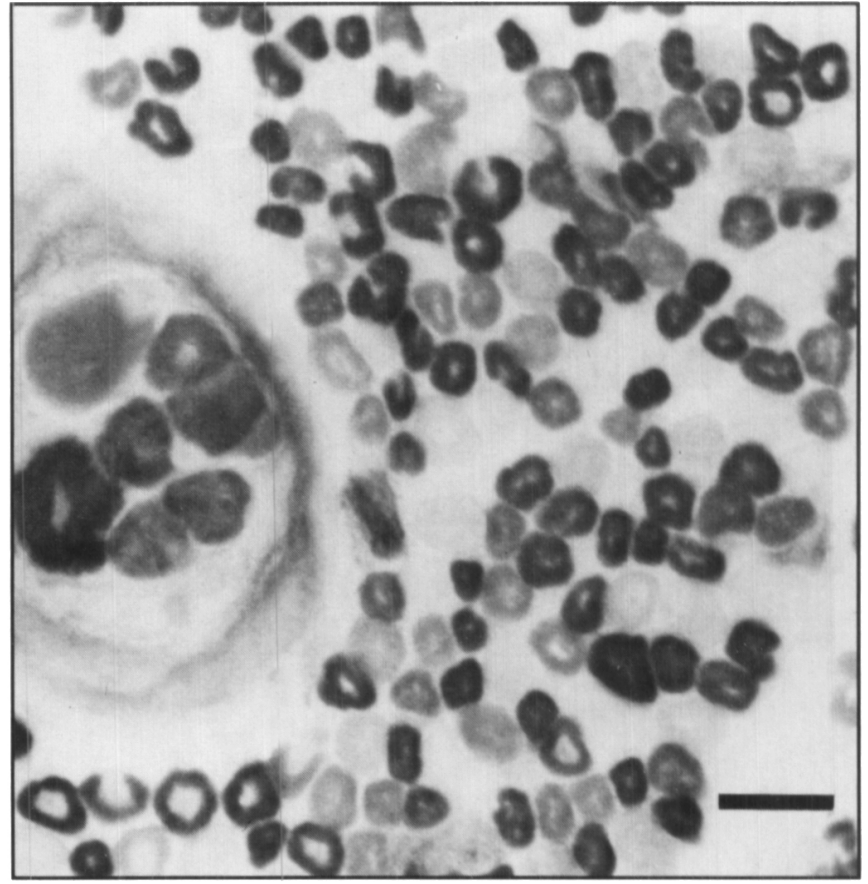

Figure 18 - Frozen cross-section of muscle from term infant with myoubular myopathy, stained with myofibrillar ATPase preincuhated at $\mathrm{pH}$ 4.6. Good differentiation of fibre types is secn despite the abnormal centronuclear architecture of the myofibres. No staining is seen in the centres of fibres that contain no myofibrils. The relative sizes of types I and II myofibres are the same. A muscle spindle (left) also show's differentiation of intrafusal fibres that are larger than the abnormally small extrafusal centronuclear fibres. $B a r=15 \mu \mathrm{m}$.

tion are seen simultaneously in fetal muscle, but the centronuclear fibres of myotubular myopathy are uniform with relatively thick myofibrillar cylinders resembling late myotubes, and do not show the close spacing of central nuclei seen in true fetal myotubes. In this regard, regenerating myofibres in injured muscle more closely resemble fetal myotubes than do the myofibres of myotubular myopathy. The case of centronuclear myopathy in a 19-year-old woman reported by Pages et al. ${ }^{35}$ includes a photomicrograph illustrating a row of tightly packed central nuclei in longitudinal section, but their case was not the $X$ linked disease because of the patient's sex and she was not an infant. Other reported cases of neonatal myotubular myopathy showed nuclear spacing similar to our cases.

The nuclei of fetal myotubes show finely dispersed chromatin and one or two large nucleoli with loose strands of ribonucleoprotein. This fine structure suggests active transcription of RNA, as expected in rapidly growing myotubes. Most central nuclei of myofibres in neonatal myotubular myopathy, are as compact as in term neonatal muscle, but other nuclei have finely dispersed chromatin resembling fetal myotubes or intermediate between the two conditions. The finer chromatin particles of some of these nuclei in myotubular myopathy may be associated with a more active process of RNA transcription than in mature muscle because of the small size of the centronuclear fibres, suggesting an attempt to enhance protein synthesis and growth. Another interpretation is that there is less DNA than normal in myotubular myopathy. Zimmermann and Weber found a 50 percent reduction in DNA content of central and sub- 


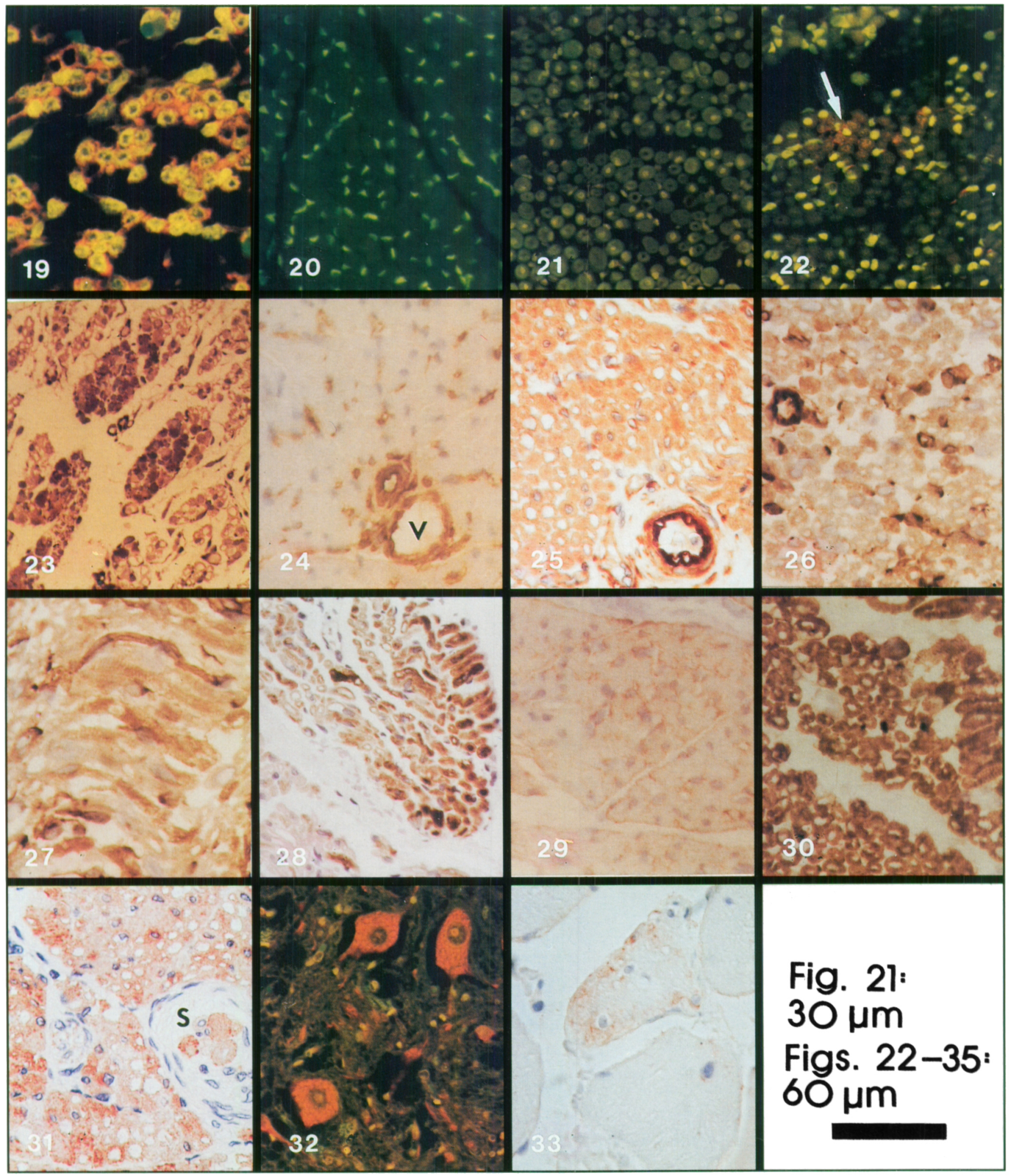


sarcolemmal nuclei from 3 brothers with centronuclear myopathy when compared with their mother, but no difference in fibroblastic nuclear DNA. ${ }^{36}$

An attempt by the small centronuclear myofibre to increase the rate of protein synthesis and growth might also account for the less condensed chromatin, because more active RNA transcription would be required. The increased RNA fluorescence detected by $\mathrm{AO}$ in some myofibres of myotubular myopathy might be explained by this feature, though why it is not uniform and present in all centronuclear fibres is uncertain. AO-RNA fluorescence of some myofibres in neonatal myotubular myopathy was previously reported 37 and is again confirmed in this study. The orange-red fluorescence is less intense than that seen in fetal myotubes, however. Ribosomes are abundant in regions of myofilament assembly in fetal muscle. ${ }^{38}$ They are structurally related to the formation of thick myosin filaments, but not of thin actin filaments. ${ }^{39}$ Ribosomes rapidly decrease in number to virtually disappear as the sarcomeres are formed, and RNA fluorescence of mature neonatal muscle fibres is not detected by AO. ${ }^{37} \mathrm{~A}$ greatly increased number of ribosomes were demonstrated in cultured muscle cells from infants with $\mathrm{X}$-linked myotubular myopathy. 40

The sarcotubular system of myofibres in myotubular myopathy is well formed as in the term neonate and unlike the 8-15 week fetus. Triads formed by a T-tubule flanked by a pair of terminal cisternae of sarcoplasmic reticulum are well developed, but their orientation is not well regulated. When triads form at 18-24 weeks gestation, they are parallel to the long axis of the myofibre; with further maturation they rotate $90^{\circ}$ to become perpendicular to the long axis. ${ }^{41,42}$ In the 31 week fetus, various orientations are found, but at term nearly all triads are oriented perpendicular to the long axis of the myofibre. In myotubular myopathy, a larger number of longitudinal and obliquely oriented triads were demonstrated than in term neonatal muscle. This is not necessarily evidence of immaturity; it may simply be a mechanical function of the failure of anatomical reorganization of the myofibre. In this regard, it is noteworthy that desmin filaments attach to nuclei, to mitochondria, and to the sarcolemmal membrane, but not to T-tubules or triads. ${ }^{43}$ Ambler et al. reported a proliferation of sarcotubular organelles as elaborate stacks of tubules in X-linked myotubular myopathy, a feature not seen in fetal or mature neonatal muscle. ${ }^{8}$ Duplication of triads and other anomalies of the sarcotubular system have been reported in individual cases. 22,44

$\mathrm{Z}$-band registry, the alignment of Z-bands of adjacent myofibrils within a myofibre, does not occur until about 30 weeks gestation and fine desmin filaments provide the physical means of maintaining this register in both the relaxed and contracted states. The Z-bands of fetal myotubes lack this register (Figure 8B), but those of myotubular myopathy are as precisely organized as in mature neonatal or adult muscle (Figure 11).

The scattered degenerating myotubes in fetal muscle, that represent a physiological process of programmed cell death, 45,46 were not observed ultrastructurally or histologically involving any centronuclear myofibres in our cases of myotubular myopathy. Scattered necrotic myofibres are reported only rarely in centronuclear myopathies. 17.47 Some authors have speculated upon a focal degenerative process in the pericentronuclear zones. 19,35,48 Autofluorescent lipochrome pigment was demonstrated in the central cytoplasmic core between nuclei in some

\section{PLATES}

Figure 19-Myotubes of 12 week human fetus show' strong cytoplasmic RNA fluorescence with acridine orange. Cryostat section.

Figure 20-Cross-section of normal muscle from full-term neonate show's no orange-red fluorescence after staining with acridine orange. Cryostat section.

Figures 21 and 22 - Cross-section of muscle from two neonates with myotubular myopathy. Most centronuclear myofibres show' no orange RNA fluorescence with acridine orange, but some fibres, in small groups, are positive (arrow), though never as strong as in fetal myotubes. The yellow fluorescence is muclear DNA. Cryostat section.

Figure 23 - Myotubes of human fetal muscle of 12 weeks gestation in cross-section. Strong immunoreactivity for vimentin is seen. Paraffin section.

Figure 24 - Full-term neonate show's no immunoreactivity for vimentin in myofibres, but smooth muscular walls of blood vessels (v) and endothelial cells continue to express vimentin in the mature state. Cryostat section.

Figures 25-27 - Muscle of three neonates with myotubular myopathy. Myofibres express immunoreactivity for vimentin, and immature feature. Cryostat sections (Figures 27, 28); paraffin section (Figure 29).

Figure 28 - Fetal myotubes show strong immunoreactivity for desmin. Paraffin section.

Figure 29-Myofibres of full-term neonate exhibit no reaction for desmin. Cryostat section.

Figure 30 - Neonatal myotuhular myopathy is characterized by myofibres showing immunoreactivity for desmin as strong as in true fetal myotubes. Cryostat section.

Figure 31 - Another neonate with myotubular myopathy showing strong expression of desmin in centronuclear fibres. Intrafusal muscle fibres of muscle spindle (s) are involved as well as the extrafusal fibres. Paraffin section.

Figure 32 - Motor neurons of lumbar segment of spinal cord of neonate dying with myoubular myopathy show no morphological abnormalities and normal intensity and distribution of ribosomal RNA with acridine orange fluorochrome. This appearance is unlike the RNA fluorescence in ischaemic/hypoxic injury, axonal injury, and spinal muscular atrophy, and provides evidence against a neurogenic mechanism of myotubular myopathy.

Figure 33-An atrophic centronuclear muscle fibre in the biopsy of the asymptomatic mother of one of the cases of myotubular myopathy shows immunoreactivity for desmin. Adjacent fibres do not express desmin. Paraffin section. 
cases. 49 The perinuclear zone may show myofibrillar degeneration, membranous debris, myelin figures, and empty vesicular structures by electron microscopy, 48,50 but most cases including ours show only numerous mitochondria and glycogen granules.

The hypothesis that the pathogenesis of myotubular myopathy is neurogenic has been attractive to many authors because myotubes do not mature without innervation either in tissue culture or in vivo. A model of maturational arrest in the myotubular stage in the gastrocnemius muscle of the rat is induced by neonatal sciatic neurotomy. ${ }^{51}$ Many authors have presented electrophysiological, morphological, or histochemical findings suggesting neuropathy in myotubular myopathy, $5,8,26,52-56$ but the evidence is far from conclusive. Structural abnormalities in spinal motor neurons or a decrease in their number have not been shown in any postmortem study including the cases here reported. AO fluorescence was shown in the present study to demonstrate a normal cytoplasmic distribution of RNA, by contrast with the severe and specific types of alterations shown by this method in infantile spinal muscular atrophy 57 and following perinatal asphyxia. ${ }^{58}$ Intramuscular nerves exhibit no alterations in either axoplasm or in myelin sheaths. Motor end-plates are well formed in skeletal and in extraocular muscles in myotubular myopathy. 55.59.60 Extrajunctional acetylcholine (ACh) receptors are not found on the sarcolemmal membranes in myotubular myopathy. ${ }^{60,61}$ An absence of such extrajunctional $\mathrm{ACh}$ receptors suggests that any alteration of the sequence of events in nerve-muscle development in myotubular myopathy occurs after innervation, though the immunoperoxidase method may not be sensitive enough to demonstrate these receptors. ${ }^{61}$

The mature histochemical differentiation of myofibres by myofibrillar ATPase criteria in myotubular myopathy is further evidence that a neurogenic pathogenesis is not likely. Histochemical differentiation of human muscle occurs at 20-28 weeks gestation, ${ }^{62-66}$ well after the myotubular stage. It is neurally induced and remains mutable even in the adult. Some cases of centronuclear myopathy are associated with selective smallness of histochemical type I myofibres, ${ }^{10,18,67-70}$ central nuclei confined to type I fibres ${ }^{36.67}$ or to type II fibres, 54 or a massive type I fibre predominance or even total lack of differentiation of type II fibres. $0,21,71$ Whether these cases are all the same disease or have the same pathogenesis is doubtful, but neither type I fibre hypotrophy nor type I fibre predominance is evidence of a neural mechanism and neither corresponds to a normal stage of muscle ontogenesis. An increased proportion of subtype IIc fibres, the least differentiated histochemical type, also is reported, 56 but is not specific because it occurs commonly in muscular dystrophies and other myopathies.

The strong immunoreactivity of the intermediate filament proteins vimentin and desmin in centronuclear muscle fibres in the cases here described displays a striking similarity to true fetal myotubes but does not necessarily signify a general maturational arrest. It may, however, be a single genetic deficiency in the control of regression of transitory fetal proteins. Perinuclear regions of fetal myotubes characteristically include nonoriented filaments that are intermediate in diameter (10-12 nm) between thick $(15 \mathrm{~nm})$ and thin $(8 \mathrm{~nm})$ contractile filaments, or intermediate between microfilaments $(5 \mathrm{~nm})$ and microtubules $(25$ $\mathrm{nm}) .31,38$ They also are found distal to regions of sarcomere formation. These intermediate filaments are cytoskeletal elements that maintain the position of nuclei and organelles in all cells. In muscle cells, they help organize the alignment of contractile filaments, though they themselves are not contractile. They may be important in determining the polarity of the early myotube. Vimentin is an important intermediate filament protein present in high concentrations in myoblasts and in myotubes. ${ }^{72-75} \mathrm{It}$ is strongly expressed in late myotubes, but rapidly decreases with further maturation and is no longer demonstrable during the second half of gestation or in mature striated muscle. It persists in vascular smooth muscle throughout life.

Desmin is another important intermediate filament of striated muscle, responsible for maintaining the registry of Z-bands by forming linkages. Filaments of desmin also attach to nuclei, mitochondria; and sarcolemmal membranes, but not to T-tubules. ${ }^{43}$ Desmin synthesis is initiated at the time of myoblast fusion and is prominent in fetal myotubes, having the same distribution as vimentin. ${ }^{73,74}$ Mononucleated myoblasts have a higher concentration of vimentin than desmin. After myoblast fusion and the formation of the multinucleated myotube, the concentration of vimentin decreases as the level of desmin increases. ${ }^{72,76,77}$ In early myotubes, a 1:3 ratio of vimentin/desmin is maintained. 78 Vimentin and desmin coexist in cardiac and smooth muscle as well as in skeletal muscle. ${ }^{79-82}$ The immunoreactivity of these intermediate filaments, particularly desmin, also is a marker of rhabdomyosarcoma. ${ }^{83}$ In striated muscle, desmin filaments begin to redistribute themselves transversely at the time of sarcomere formation. ${ }^{75}$ Desmin is present in concentrations too low to easily demonstrate immunocytochemically in mature human muscle, but its presence is detected by special electrophoretic and immunological methods. ${ }^{84}$ The sparse strands of desmin in adult muscle are nevertheless important in connecting myofibrils at the Z-bands to adjacent sarcolemma, mitochondria, and nuclei, and in maintaining the relative positions of these structures during contraction of the muscle.

The abundance of vimentin and desmin demonstrated in the myofibres of infants with myotubular myopathy in this study provides a theoretical basis for explaining the immature morphology of the centronuclear myofibres. Nuclei may remain as a central row because the persistent vimentin and desmin prevents their "migration" to the subsarcolemmal position as the myofibre matures. Mitochondria similarly are held in place and prevented from becoming redistributed within the intermyofibrillar sarcoplasm. The structural conservation of intermediate filaments in mouse glial cells is linked to genetic encoding. ${ }^{85}$ Altered expression of genes for cytoskeletal proteins has been demonstrated in human cerebral cortical neurons in Alzheimer disease. 86 Myotubular myopathy may be another disease with a similar pathogenetic mechanism expressed in a different system.

The possibility that increased vimentin and desmin are nonspecific features of any neuromuscular disease must be considered. A preliminary survey of paediatric neuromuscular diseases, applying vimentin and desmin immunocytochemistry to muscle biopsies, reveals that regenerating myofibres have demonstrable vimentin and desmin in Duchenne muscular dytrophy and in juvenile dermatomyositis with perifascicular atrophy, but that these same fibres always show strong AORNA fluorescence. Most muscle fibres are negative for vimentin and desmin despite internal nuclei and other cytoarchitectural alterations. Infantile spinal muscular atrophy usually 
shows absence of demonstrable vimentin in both atrophic and hypertrophic myofibres, but some atrophic fibres react to antidesmin antibodies. Certain other neonatal myopathies are suspected of being due to delay or arrest of muscle maturation, notably the severe neonatal form of myotonic dystrophy. 87.88 Our preliminary results suggest that myofibres in this disease uniformly react for desmin but not vimentin. Dysplasias of the developing brain and especially of posterior fossa structures appear to have a suprasegmental influence on the developing motor unit and alter its maturation. ${ }^{89}$ These disorders and centronuclear myopathies in older children and adults are also presently under investigation in our laboratory.

Several scattered case reports describe unclassified myopathies in which dense aggregates or bundles of intermediate filaments are identified within skeletal myofibres by electron microscopy. $90-94$ They are present within the subsarcolemmal and intermyofibrillar sarcoplasm, often in relation to the Z-band of sarcomeres. These intermediate filaments react strongly with anti-desmin antibodies and none show immunoreactivity to vimentin. In one report, a rare cardiomyopathy showed similar findings in cardiac myofibres and a lesser excess of desmin filaments in skeletal muscle. ${ }^{95}$ It is unlikely that these myopathies are related to neonatal myotubular myopathy, but they suggest that desmin is probably less specific than vimentin as a pathogenetic factor.

A reliable means of detecting the maternal carrier state in $\mathrm{X}$ linked myotubular myopathy is not presently available for genetic counseling. Muscle biopsies of mothers of infants with the severe neonatal disease often show mild focal myopathic changes, such as excessive variation in fibre diameter, scattered centronuclear fibres, or mild cytoarchitectural alterations..$^{5,6,11,90}$ The three cases in the present study whose mothers underwent muscle biopsy showed such maternal changes, which were interpreted as consistent with the $\mathrm{X}$-linked recessive disease. Other authors identify no morphological or histochemical alterations in maternal muscle biopsies, however.9,10,36,68 The presence of immunocytochemically demonstrable vimentin and desmin in scattered maternal myofibres (Figure 35) may be more specific than any of the other reported histological variations, and the lack of AO-RNA fluorescence of these myofibres distinguishes them from simple regeneration. Vimentin/desmin might also provide a marker useful in prenatal diagnosis at 1820 weeks gestation, because the quantity of these proteins in fetal muscle declines sharply after 15 weeks. The method by which it might be employed in a manner less invasive than fetal muscle biopsy in utero requires further investigation.

The genetic mechanism is complex if vimentin and desmin are primary in the pathogenesis of myotubular myopathy. The linkage site of the defective gene in X-linked myotubular myopathy has recently been identified at the Xq28 locus, 97,98 a different site from the $\mathrm{Xp} 21$ locus of Duchenne muscular dystrophy. Genes encoding the synthesis of human vimentin and desmin are located on different autosomes, vimentin on chromosome $10(10 \mathrm{p} 13)^{99.100}$ and desmin on chromosome 2 (2q35).99.101

The present study suggests that myotubular myopathy is an arrest of morphogenesis of the developing myofibre rather than a general maturational arrest of muscle, and that innervation is normal and plays no role. The pathogenesis may be persistently high fetal concentrations of vimentin and desmin in the myofi- bre, cytoskeletal protein filaments that preserve the normally transitory central positions of nuclei and mitochondria within the myotube. Vimentin/desmin immunocytochemical study of the muscle biopsy of affected infants may confirm the diagnosis, and may also be useful in identifying the asymptomatic carrier state of X-linked myotubular myopathy in the maternal muscle biopsy.

\section{ACKNOWLEDGEMENT}

I wish to thank Drs. NB Rewcastle and WS Hwang, Department of Pathology, and Dr. AKW Brownell, Department of Clinical Neurosciences, University of Calgary, for reading the manuscript and offering valuable suggestions. Dr. Brownell also kindly provided Patient 4 and the maternal muscle biopsy of that case. Pathology Assistants J Ouellette and L Murphy helped procure fetal tissues. Tissue preparation for histology and histochemistry was provided by $L$ Marwood, T de Graaf, L Oke, and B Fretwell of Fooothills Provincial General Hospital and by L Hines of Alberta Children's Hospital. Technical assistance for immunohistochemistry was provided by $M$ Tanaka, S Hui and F Jahelka, and for electron microscopy by I Gedeon and W Chan at Foothills Hospital. This work was supported by grants from the Alberta Children's Hospital Foundation and the MSI Foundation of Alberta.

\section{REFERENCES}

1. Spiro AJ, Shy GM, Gonatas NK. Myotubular myopathy. Arch Neurol 1966; 14: 1-14.

2. Kinoshita M, Cadman TE. Myotubular myopathy. Arch Neurol 1968; 18: 265-271.

3. Badurska B, Fidziańska A, Kamieniecka Z, et al. Myotubular myopathy. J Neurol Sci 1969; 8: 563-571.

4. Edström L, Wróblewski R, Mair WGP. Genuine myotubular myopathy. Muscle Nerve 1982; 5; 604-613.

5. Sarnat HB, Roth SI, Jimenez JF. Neonatal myotubular myopathy: neuropathy and failure of postnatal maturation of fetal muscle. Can J Neurol Sci 1981; 8: 313-320.

6. Sher JH, Rimalovski AB, Athanassiades TJ, et al. Familial centronuclear myopathy: a clinical and pathological study. Neurology 1967; 17: 727-742.

7. Munsat TL. Thompson LR, Coleman RF. Centronuclear ("myotubular") myopathy. Arch Neurol 1969; 20: 120-131.

8. Ambler MW, Neave C, Singer DB. X-linked recessive myotubular myopathy. II. Muscle morphology and human myogenesis. Hum Pathol 1984; 15: 1107-1120.

9. Van Wijngaarden GK, Fleury P, Meijer AEFH. Familial "myotubular" myopathy. Neurology 1969; 19: 901-908.

10. Myers KR, Golomb HM, Hansen JL, et al. Familial neuromuscular disease with myotubes. Clin Genet 1974; 5: 327-337.

11. Barth PG, Van Wijngaarden GK, Bethlem J. X-linked myotubular myopathy with fatal neonatal asphyxia. Neurology $1975 ; 25$ : $531-536$.

12. Ilina NA, Averyanov UN, Potomskaya LZ, et al. X-linked myotubular myopathy (in Russian). Zh Nevropathol Psikhiatr Im SS Korsakova 1979; 79: 1334-1338.

13. Bucher HU, Boltshauser E, Briner J, et al. Severe neonatal centronuclear (myotubular) myopathy: an X-linked recessive disorder. Helv Paediatr Acta 1986; 41:291-300.

14. Silver MM, Gilbert JJ, Stewart S, et al. Morphologic and morphometric analysis of muscle in X-linked myotubular myopathy. Hum Pathol 1986; 17: 1167-1178.

15. Keppen LD, Husain MM, Wood RC. X-linked myotubular myopathy: intrafamilial variability and normal muscle biopsy in a heterozygous female. Clin Genet 1987; 32: 95-99.

16. Palmucci L, De Angelis S, Leone M, et al. Centronuclear myopathy: type of inheritance and clinical pattern in 268 cases. Clin Neuropathol 1988; 7: 194 (abstract).

17. Pépin B, Mikol J, Goldstein B, et al. Forme familiale de myopathie centronucléaire de l'adulte. Rev Neurol (Paris) 1976; 132: 845-857. 
18. Bradley WG, Price DL, Watanabe CK. Familial centronuclear myopathy. J Neurol Neurosurg Psychiatry 1970; 33: 687-698.

19. Torres CF, Griggs RC, Goetz JP. Severe neonatal centronuclear myopathy with autosomal dominant inheritance. Arch Neurol 1985; 42: $1011-1014$

20. Radu H, Killyen I, Ionescu V, et al. Myotubular (centronuclear) (neuro-) myopathy. I. Clinical, genetical and morphological studies. Eur Neurol 1977; 15: 285-300.

21. Martin JJ, Ceuterick J, Joris C, et al. Myopathie centro-nucléaire. Acta Neurol Belg 1977; 77: 285-299.

22. Raju TNK, Vidyasagar D, Reyes MG, et al. Centronuclear myopathy in the newborn period causing severe respiratory distress syndrome. Pediatrics 1977; 59: 29-34.

23. Palmucci L, Bertolotto A, Monga $G$, et al. Histochemical and ultrastructural findings in a case of centronuclear myopathy. Eur Neurol 1978; 17: 327-332.

24. PeBenito R, Sher JH, Cracco JB. Centronuclear myopathy: clinical and pathologic features. Clin Pediatr 1978; 17: 259-265.

25. Larbrisseau A, Brochu $\mathrm{P}$, Vanasse $\mathrm{M}$, et al. Les myopathies congénitales. Observation de 9 cas et revue générale. L'Union Méd Canada 1980; 109: 256-276.

26. Collins JE, Collins A, Radford MR, et al. Perinatal diagnosis of myotubular (centronuclear) myopathy: a case report. Clin Neuropathol 1983; 2: 79-82.

27. Heckmatt JZ, Sewry CA, Hodes D, et al. Congenital centronuclear (myotubular) myopathy. Brain 1985; 108: 941-964.

28. Strom EH, Tangsrud SE. Craniopharyngioma in a boy with centronuclear (myotubular) myopathy: clinical and postmortem findings. Clin Neuropathol 1986; 5: 84-87.

29. Inokuchi T, Umezaki H, Santa T. A case of type I muscle fibre hypotrophy and internal nuclei. J Neurol Neurosurg Psychiatry 1975; 38: 475-482.

30. Jandro-Santel D. Centronuclear myopathy with type I fibre hypotrophy and fingerprint inclusions associated with Marfan's syndrome. J Neurol Sci 1980; 45: 43-56.

31. Tomanek RJ, Colling-Saltin A-S. Cytological differentiation of human fetal skeletal muscle. Am J Anat 1977; 149: 227-246.

32. Fidziańska A. Human ontogenesis. I. Ultrastructural characteristics of developing human muscle. J Neuropathol Exp Neurol 1980; 39: 476-486.

33. Minguetti G, Mair WGP. Ultrastructure of developing muscle. Biol Neonate 1981; 40: 276-294.

34. Sarnat HB. Ontogenesis of striated muscle. In: Polin RA, Fox WW, eds. Neonatal and Fetal Medicine: Physiology and Pathophysiology. Orlando, Florida: WB Saunders 1990; (in press).

35. Pages M, Cesari JB, Pages AM. La myopathie centronucléaire Revue complète de la littérature á propos d'un cas. Ann Pathol (Paris) 1982; 2: 301-310.

36. Zimmermann $P$, Weber V. Familial centronuclear myopathy: a haploid DNA disease? Acta Neuropathol 1979; 46: 209-214.

37. Sarnat HB. L'acridine-orange: un fluorochrome pour l'étude des cellules musculaires et nerveuses. Rev Neurol (Paris) 1985; 141: 120-127.

38. Kelly DE. Myofibrillogenesis and Z-band differentiation. Anat Rec 1969; 163: 403-426.

39. Larson PF, Hudgson P, Walton JN. Morphological relationship of polyribosomes and myosin filaments in developing and regenerating skeletal muscle. Nature 1969; 222: 1168-1169.

40. Askanas V, Engel WK, Reddy NB, et al. X-linked recessive congenital muscle fiber hypotrophy with central nuclei. Abnormalities of growth and adeylate cyclase in muscle tissue cultures. Arch Neurol 1979; 36: 604-609.

41. Edge MB. Development of apposed sarcoplasmic reticulum at the T-system and sarcolemma and the change in orientation of triads in rat skeletal muscle. Dev Biol 1970; 23: 634-650.

42. Walker SM, Schrodt GR, Currier GJ, et al. Relationship of the sarcoplasmic reticulum to fibril and triadic junction development in skeletal muscle fibers of fetal monkeys and humans. J Morphol 1975; 146: 97-128.

43. Tokuyasu KT, Dutton AH, Singer SJ. Immunoelectron microscopic studies of desmin (skeletin) localization and intermediate fil- ament organization in chicken skeletal muscle. J Cell Biol 1983; 96: 1727-1735.

44. Bill PLA, Cole G, Proctor NSF. Centronuclear myopathy. J Neurol Neurosurg Psychiatry 1979; 42: 548-556.

45. Hayes VE, Hikida RS. Naturally-occurring degeneration in chick muscle development; ultrastructure of the $M$. complexus. J Anat 1976; 122: 67.76.

46. Webb JN. The development of human skeletal muscle with particular reference to muscle cell death. J Pathol 1972; 106: 221 229.

47. Goulon L, Fardeau M, Got C, et al. Myopathie centro-nucléaire d'expression tardive. Étude clinique, histologique et ultrastructurale. Rev Neurol (Paris) 1976; 132: 275-290.

48. Campbell MJ, Rebeiz JJ, Walton JN. Myotubular, centronuclear or pericentronuclear myopathy? J Neurol Sci 1969; 8: 425-443.

49. Headington JT, McNamara JO, Brownell AK. Centronuclear myopathy: histochemistry and electron microscopy. Report of 2 cases. Arch Pathol 1975; 99: 16-24.

50. Schochet SS, Zellweger H, Ionasescu V, et al. Centronuclear myopathy: disease entity or a syndrome? J Neurol Sci 1972; 16: 215-228.

51. Engel WK, Karpati G. Impaired skeletal muscle maturation following neonatal neurectomy. Dev Biol 1968; 17: 713-723.

52. Pongratz D, Heuser M, Mittelbach F, et al. Die sogenannte congenitale centronucleäre Myopathie - eine primäre Neuropathie? Acta Neuropathol 1975; 32: 9-19.

53. Coërs C, Telerman-Toppet N, Gérard JM, et al. Changes in motor innervation and histochemical pattern of muscle fibers in some congenital myopathies. Neurology 1976; 26: 1046-1053.

54. Sugie H, Rasmussen GE, Verity MA. Adult onset type Il fiber centronuclear neuromyopathy with segmental demyelination. Brain Dev (Tokyo) 1982; 4: 7-12.

55. Elder GB, Dean D, McComas AJ, et al. Infantile centronuclear myopathy. Evidence suggesting incomplete innervation. J Neurol Sci 1983; 60: 79-88.

56. Sasaki T, Shikura K, Sugai K, et al. Muscle histochemistry in myotubular (centronuclear) myopathy. Brain Dev (Tokyo) 1989; 11:26-32.

57. Sarnat HB, Jacob P, Jiménez M. Atrophie spinale musculaire: l'évanouissement de la fluorescence á l'ARN des neurones moteurs en dégénérescence: une étude à l'acridine-orange. Rev Neurol (Paris) 1989; 145: 305-311.

58. Sarnat HB. Hypoxic alterations in neonatal neurons: an acridine orange fluorochromic study of nucleic acids. Brain Dev (Tokyo) 1987; 9: 43-47.

59. Bender AN, Bender MB. Muscle fiber hypotrophy with intact neuromuscular junctions. Neurology 1977; 27: 206-212.

60. Bergen BJ, Carry MP, Wilson WB, et al. Centronuclear myopathy: extraocular- and limb-muscle findings in an adult. Muscle Nerve 1980; 3: 165-171.

61. Ringel SP, Bender AN, Engel WK. Extrajunctional acetylcholine receptors. Arch Neurol 1976; 33: 751-758.

62. Dubowitz V. Enzymatic maturation of skeletal muscle. Nature 1963; 197: 1215 .

63. Fenichel GM. A histochemical study of developing human skeletal muscle. Neurology 1966; 16: 741-745.

64. Farkas-Bargeton E, Diebler MF, Arsénio-Nunes ML, et al. Étude de la maturation histochimique, quantitative et ultrastructurale du muscle foetal humain. J Neurol Sci 1977; 31: 245-259.

65. Colling-Saltin A-S. Enzyme histochemistry on skeletal muscle of the human foetus. J Neurol Sci 1978; 39: 169-185.

66. Kumagai T, Hakamada $S$, Hara $K$, et al. Development of human fetal muscles: a comparative histochemical analysis of the psoas and the quadriceps muscles. Neuropediatrics 1984; 15: 198-202.

67. Engel WK, Gold GN, Karpati G. Type I fiber hypotrophy and central nuclei. Arch Neurol 1968; 18: 435-444.

68. Bethlem J, Van Wijngaarden GK, Meijer AEFH. Neuromuscular disease with type I fiber atrophy, central nuclei, and myotubelike structures. Neurology 1969; 19: 705-710.

69. Karpati G, Carpenter S, Nelson RF. Type I fibre atrophy and central nuclei: a rare familial neuromuscular disease. J Neurol Sci 1970; 10: 489-500. 
70. Kinoshita M, Satoyoshi E, Matsuo N. "Myotubular myopathy" and "type I fibre atrophy" in a family. J Neurol Sci 1975; 26: 575-582.

71. Serratrice G, Pellissier JF, Faugère MC, et al. Centronuclear myopathy: possible central nervous system origin. Muscle Nerve 1978; 1: 62-69.

72. Bennett GS, Fellini SA, Toyama Y, et al. Redistribution of intermediate filament subunits during skeletal myogenesis and maturation in vitro. J Cell Biol 1979; 82: 577-584.

73. Gard DL, Lazarides E. The synthesis and distribution of desmin and vimentin during myogenesis in vitro. Cell 1980; 19: 263275.

74. Tokuyasu KT, Dutton AH, Singer SJ. Distribution of vimentin and desmin in developing chick myotubes in vivo. I. Immunofluorescence study. J Cell Biol 1984; 98: 1961-1972.

75. Tassin A-M, Pinçon-Raymond $M$, Paulin D, et al. Unusual organization of desmin intermediate filaments in muscular dysgenesis and TTX-treated myotubes. Dev Biol 1988; 129: 37-47.

76. Holtzer H, Bennett GS, Tapscott SJ, et al. Intermediate-size filaments: change in synthesis and distribution in cells of the myogenic and neurogenic lineages. Quant Biol 1982; 46: 317-329.

77. Tokuyasu KT, Maher PA, Dutton AH, et al. Intermediate filaments in skeletal and cardiac muscle tissue in embryonic and adult chicken. Ann. NY Acad Sci 1985; 455: 200-212.

78. Tassin A-M, Maro B, Bornens $M$. Fate of microtubule organizing centers during myogenesis in vitro. J Cell Biol 1985; 100: 3546.

79. Berner PF, Frank E, Holtzer $\mathrm{H}$, et al. The intermediate filament proteins of rabbit vascular smooth muscle: immunofluorescent studies of desmin and vimentin. J Muscle Res Cell Motil 1981; 2: 439-452.

80. Schmid E, Osborn M, Rungger-Brandle E, et al. Distribution of vimentin and desmin filaments in smooth muscle tissue of mammalian and avian aorta. Exp Cell Res 1982; 137: 329-340.

81. Fujimoto T, Singer SJ. Immunocytochemical studies of desmin and vimentin in pericapillary cells of chicken. J Histochem Cytochem 1987; 35: 1105-1112.

82. Osinska HE, Lemanski LF. Immunofluorescent localization of desmin and vimentin in developing cardiac muscle of Syrian hamster. Anat Rec 1989; 223: 406-413.

83. Battifora $H$. Desmin and sarcomeric myosins in the diagnosis of rhabdomyosarcoma. In: De Lellis RA, ed: Advances in Immunohistochemistry. New York: Raven Press 1988.

84. Tokuyasu KT, Maher SA, Singer SJ. Distributions of vimentin and desmin in developing chick myotubes in vivo. II. Immunoelectron microscopic study. J Cell Biol 1985; 100: $1157-1166$

85. Lewis SA, Balcarek JM, Krek V, et al. Sequence of a cDNA clone encoding mouse glial fibrillary acidic protein: structural conservation of intermediate filaments. Proc Natl Acad Sci USA 1984; 81: 2743-2746.

86. Clark AW, Krekoski CA, Parhad IM, et al. Altered expression of genes for amyloid and cytoskeletal proteins in Alzheimer cortex. Ann Neurol 1989; 25: 331-339.
87. Sarnat HB, Silbert SW. Maturational arrest of fetal muscle in neonatal myotonic dystrophy. A pathologic study of four cases. Arch Neurol 1976; 33: 466-474.

88. Farkas-Bargeton E, Barbet JP, Dancea $S$, et al. Immaturity of muscle fibres in the congenital form of myotonic dystrophy: its consequences and its origin. J Neurol Sci 1988; 83: 145-159.

89. Sarnat HB. Le cerveau influence-t-il le développement musculaire du foetus humain? Mise en évidence de 21 cas. Can J Neurol Sci 1985; 12: 111-120.

90. Fardeau M, Godet-Guillain J, Tomé FMS, et al. Une nouvelle affection musculaire familiale définie par l'accumulation intrasarcoplasmique d'un materiel granulofilamentaire dense en microscopie électronique. Rev Neurol (Paris) 1978; 134: 411425.

91. Edström L, Thornell LE, Eriksson A. A new type of hereditary distal myopathy with characteristic sarcoplasmic bodies and intermediate (skeletin) filaments. J Neurol Sci 1980; 47: 171190.

92. Fidziańska A, Goebel M, Osborn M, et al. Mallory body-like inclusions in a hereditary congenital neuromuscular disease. Muscle Nerve 1983; 6: 195-200.

93. Osborn M, Goebel HH. The cytoplasmic bodies in a congenital myopathy can be stained with antibodies to desmin, the musclespecific intermediate filament protein. Acta Neuropathol 1983; 62: $149-152$.

94. Pellissier JF, Pouget J, Charpin C, et al. Myopathy associated with desmin type intermediate filaments. An immunoelectron microscopic study. J Neurol Sci 1989; 89: 49-61.

95. Stoeckel M-E, Osborn M, Porte A, et al. An unusual familial cardiomyopathy characterized by aberrant accumulations of desmin-type intermediate filaments. Virch Arch Pathol Anat 1981; 393: 53-60.

96. Coleman FR, Thompson LR, Neihuis AW, et al. Histochemical investigation of myotubular myopathy. Arch Pathol 1968; 86: 365-375.

97. Thomas NST, Sarfarazi M, Roberts K, et al. X-linked myotubular myopathy: evidence for linkage to $\mathrm{Xq} 28$ DNA markers. Cytogenet Cell Genet 1987; 46: 704 (abstract).

98. Darfors C, Borje Larsson HE, Oldfors A, et al. X-linked myotubular myopathy. A linkage study. Cytogenet Cell Genet 1989; 51: 983 (abstract).

99. Quax W, Meera Khan P, Quax-Jeuken Y, et al. The human desmin and vimentin genes are located on different chromosomes. Gene 1985; 38: 189-196.

100. Ferrari S, Cannizzaro LA, Battini R, et al. The gene encoding human vimentin is located on the short arm of chromosome 10 . Am J Hum Genet 1987; 41: 616-626.

101. Viegas-Péquignot E, Zhen Lin L, Dutrillaux B, et al. Assignment of human desmin gene to band $2 \mathrm{q} 35$ by nonradioactive in sifu hybridization. Hum Genet 1989; 83: 33-36. 